\title{
POTENTIALS OF LIGNOCELLULOSIC AGRICULTURAL RESIDUES IN PAPER PRODUCTION
}

\author{
Ivana Plazonić*, Maja Rudolf*, Valentina Radić Seleš ${ }^{*}$ Irena Bates*, Katja Petric Maretić* \\ ${ }^{*}$ University of Zagreb, Faculty of Graphic Arts, Zagreb, Croatia
}

corresponding author: Ivana Plazonić, e-mail: ivana.plazonic@grf.unizg.hr

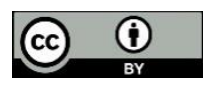

This work is licensed under a

Creative Commons Attribution 4.0

International License
Original scientific paper

Received: June $11^{\text {th }}, 2020$

Accepted: June 29 ${ }^{\text {th }}, 2020$

HAE-1965

https://doi.org/10.33765/thate.11.3.1

\begin{abstract}
Surface characteristics of printing substrates are of the utmost importance to all types of paper that interact with ink. During all types of printing processes, the behaviour of the liquid phase (ink or dye) on the paper is directly defined by the paper cellulose-based surface. The printed ink spreads and penetrates more into paper fibres when the paper surface is rougher and more permeable. Contact angle measurements by sessile drop method are considered the most appropriate for determining the paper sheet surface energy. Paper as hydrophilic material has a high absorption rate resulting in a low contact angle. The objective of this study was to evaluate the surface free energy of laboratory-made papers containing straw pulp obtained from residues after the harvest of the most cultivated cereals in Croatia (wheat, barley and triticale). The obtained surface free energy results are promising for straw pulp usage in the manufacture of printing paper.
\end{abstract}

Keywords: laboratory paper, straw pulp, contact angle, surface free energy, sessile drop method

\section{INTRODUCTION}

Proper choice of raw material for pulp and paper production is a very important part of papermaking industry. As a traditional raw material, wood is still the most common used source, but the utilization of non-wood sources in papermaking has been increasing in the last few years. The straw, as a harvesting residue, is a fibre resource available from the annually renewable crops, produced abundantly in numerous regions all over the world. Straw of the most cultivated cereals in Croatia (wheat, barley and triticale) was chosen for analysis of its suitability for pulp and paper production.
Previous research based on the chemical composition of straw has indicated how wheat, barley and triticale straw can bring competitiveness and vitality to the paper industry as an alternative non-wood raw material [1]. Straw of the above-mentioned species has nearly the same cellulose content as most wood species, lower content of lignin and higher amount of ash and solvent extractives. The research presented in this paper focuses on the possibility of obtaining pulp from the wheat, barley and triticale straw as well as its use in producing printing substrates at a laboratory scale. As printing processes are greatly affected by surface 
properties of substrate such as surface and interfacial tension, surface energy and adhesion, evaluation of the surface free energy is the first step for achieving a high print quality on the printing substrate [2]. Namely, each paper viewed as a potential printing substrate has a unique structure in terms of surface roughness, porosity and surface free energy which is the result of manufacturing technology [3]. For paper as a printing substrate, surface free energy measurement can provide a good understanding of paper surface properties using a relatively simple approach [4]. The surface free energy of paper can be determined from the contact angle measurement achieved by a test liquid drop on a paper substrate [5]. This indirect method to access the surface free energy of paper by measuring the contact angle with liquids of known surface tension is a fast technique based on few equations [6]. In this study, unprinted laboratory papers containing straw pulp in different weight ratios were experimentally compared to those made only from recycled wood pulp and results were associated with topographical parameters. This research is of great importance for getting better insight into paper-ink interactions which occur during any type of printing process.

\section{EXPERIMENTAL}

\section{Laboratory papers preparation}

Straw as agricultural residue after the harvest of the most cultivated cereal species in Croatia (wheat, barley and triticale) was collected, purified and manually cut into 1 to $3 \mathrm{~cm}$ long pieces. Straw of each cereal type was converted into semi-chemical pulp by soda pulping method under conditions summarized in Table 1 [7].

Table 1. Pulping conditions

\begin{tabular}{|c|c|}
\hline Straw & Pulping conditions \\
\cline { 1 - 1 } Wheat & $\begin{array}{c}\text { Temperature of } 120^{\circ} \mathrm{C} \text {, alkali level of } \\
16 \% \text { for } 60 \text { min and a } 10: 1 \text { liquid } \\
\text { biomass ratio. }\end{array}$ \\
\cline { 1 - 1 } Barley & Triticale
\end{tabular}

The obtained unbleached straw pulps were mixed with recycled wood pulp in different ratios $(10 \%, 20 \%$, and $30 \%)$. According to standard EN ISO 5269-2:2001, laboratory papers of approx. $42.5 \mathrm{~g} / \mathrm{m}^{2}$ were formed by a Rapid-Köthen sheet former (FRANK-PTI). Laboratory papers made only with recycled wood pulp were used as a reference for comparison in evaluating the surface free energy of laboratory-made papers containing straw pulp. In total, 10 types of laboratory papers were formed. Abbreviations used in marking laboratory paper samples are listed in Table 2.

Table 2. Abbreviations used for laboratory made paper samples

\begin{tabular}{|c|c|}
\hline Abbreviation & Pulp composition \\
\hline $\mathrm{N}$ & $100 \%$ recycled wood pulp \\
\hline $1 \mathrm{NW}$ & $\begin{array}{l}10 \% \text { wheat pulp }+90 \% \text { recycled } \\
\text { wood pulp }\end{array}$ \\
\hline $2 \mathrm{NW}$ & $\begin{array}{l}20 \% \text { wheat pulp }+80 \% \text { recycled } \\
\text { wood pulp }\end{array}$ \\
\hline $3 \mathrm{NW}$ & $\begin{array}{l}30 \% \text { wheat pulp }+70 \% \text { recycled } \\
\text { wood pulp }\end{array}$ \\
\hline $1 \mathrm{NB}$ & $\begin{array}{c}10 \% \text { barley pulp }+90 \% \text { recycled } \\
\text { wood pulp }\end{array}$ \\
\hline $2 \mathrm{NB}$ & $\begin{array}{c}20 \% \text { barley pulp }+80 \% \text { recycled } \\
\text { wood pulp }\end{array}$ \\
\hline $3 \mathrm{NB}$ & $\begin{array}{c}30 \% \text { barley pulp }+70 \% \text { recycled } \\
\text { wood pulp }\end{array}$ \\
\hline 1NTR & $\begin{array}{l}10 \% \text { triticale pulp }+90 \% \text { recycled } \\
\text { wood pulp }\end{array}$ \\
\hline 2NTR & $\begin{array}{l}20 \% \text { triticale pulp }+80 \% \text { recycled } \\
\text { wood pulp }\end{array}$ \\
\hline $3 \mathrm{NTR}$ & $\begin{array}{l}30 \% \text { triticale pulp }+70 \% \text { recycled } \\
\text { wood pulp }\end{array}$ \\
\hline
\end{tabular}

\section{Surface properties determination}

Surface free energy of paper sheets is assessed from contact angle measurements at room temperature of $(23.0 \pm 0.2){ }^{\circ} \mathrm{C}$ by sessile drop method using a Dataphysics OCA30 Goniometer (DataPhysics Instruments $\mathrm{GmbH}$, Filderstadt, Germany). The sessile drop method is an optical contact angle method that involves directly measuring the contact angle for a $1 \mu \mathrm{l}$ drop of a standard test liquid (whose surface tensions are known and listed in Table 3) on a horizontal solid surface of the paper 
sheet (Figure 1). Contact angles of liquids were defined from average values of twenty liquid droplets placed at different areas of the same paper sample. The CCD camera, which is a part of the Goniometer device, is used to take a drop image immediately after contact with the paper sheet.

Table 3. Surface tension and the corresponding dispersive and polar component of test liquids

\begin{tabular}{|c|c|c|c|c|}
\hline Test liquid & $\begin{array}{c}\gamma_{1} \\
(\mathrm{~mJ} \\
\left.\mathrm{m}^{-2}\right)\end{array}$ & $\begin{array}{c}\gamma_{1}^{\mathrm{d}} \\
(\mathrm{mJ} \\
\left.\mathrm{m}^{-2}\right)\end{array}$ & $\begin{array}{c}\gamma_{1}^{\mathrm{p}} \\
(\mathrm{mJ} \\
\left.\mathrm{m}^{-2}\right)\end{array}$ & $\begin{array}{c}\text { Polarity } \\
{\left[\gamma_{\mathrm{l}}^{\mathrm{p}} / \gamma_{1}^{\mathrm{d}}\right]}\end{array}$ \\
\hline Water & 72.80 & 21.80 & 51.00 & 2.34 \\
\hline Glycerol & 64.00 & 34.00 & 30.00 & 0.88 \\
\hline Formamide & 58.00 & 39.00 & 19.00 & 0.49 \\
\hline Diiodomethane & 50.80 & 50.80 & 0.00 & 0.00 \\
\hline
\end{tabular}

Surface free energy of laboratory papers was determined using the Owens, Wendt, Rabel and Kaelble (OWRK) method based on Young's equation:

$$
\gamma_{\mathrm{s}}=\gamma_{\mathrm{sl}}+\gamma_{1} \cdot \cos \theta
$$

where: $\gamma_{\mathrm{s}}$ is the total surface free energy of the solid $\left(\mathrm{mJ} \mathrm{m}^{-2}\right), \gamma_{\mathrm{sl}}$ is the interfacial tension between solid and liquid, $\gamma_{1}$ is the surface tension of the liquid, and $\theta$ is the contact angle $\left({ }^{\circ}\right)$.

The illustration of the contact angle formed by sessile liquid drop on a paper surface is presented in Figure 1 [8].

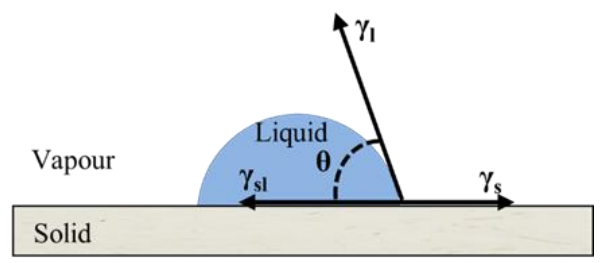

Figure 1. Diagram showing the interfacial tensions and contact angle formed by a liquid

drop which describes the interaction of Young's equation (Eq.1)

The total surface energy $\left(\gamma_{\mathrm{s}}\right)$ is divided into a dispersive part $\left(\gamma^{\mathrm{d}}\right)$ and a polar part $\left(\gamma^{\mathrm{p}}\right)$ according to the equation:

$$
\gamma_{\mathrm{s}}=\gamma^{\mathrm{d}}+\gamma^{\mathrm{p}}
$$

These calculations are integrated into the software (SCA20, Version 2.01) and are carried out automatically.

As contact angle values could be affected by the sample surface topography, the roughness of samples is also determined using a portable surface roughness tester TR200 (PortableTesters, Pittsburgh, USA). Measurements were provided by the stylus method, vertical to the paper surface. Surface roughness measurements can be described with few roughness parameters. The most commonly used parameters for analysing papers surface roughness are arithmetic mean surface roughness $\left(R_{a}\right)$ and maximum peak height $\left(\mathrm{R}_{\mathrm{z}}\right)$ which are calculated according to equations (ISO 4287-1:1997):

$$
\begin{gathered}
\mathrm{R}_{\mathrm{a}}=\frac{1}{\mathrm{~L}} \int_{0}^{1}|\mathrm{Z}(\mathrm{x})| \mathrm{dx} \\
\mathrm{R}_{\mathrm{z}}=\mathrm{R}_{\mathrm{p}}+\mathrm{R}_{\mathrm{v}}
\end{gathered}
$$

where: $R_{p}$ is the maximum profile peak height of the assessed profile and $R_{V}$ is the maximum profile valley depth of the assessed profile.

The reported $R_{a}$ and $R_{z}$ values are the average of 10 measurements corresponding to different regions and in different directions of the paper surface.

\section{RESULTS AND DISCUSSION}

The values of arithmetic mean surface roughness $\left(\mathrm{R}_{\mathrm{a}}\right)$ and maximum peak height $\left(\mathrm{R}_{\mathrm{z}}\right)$ are listed in Table $4 . R_{a}$ values of all analysed paper samples are in the range from 4.06 to $4.59 \mu \mathrm{m} . \mathrm{R}_{\mathrm{z}}$ values, as expected, cover a wider range of values from 23.14 to $31.96 \mu \mathrm{m}$. From the results, it is evident that the addition of any straw pulp into recycled wood pulp slightly increases roughness values of laboratory-made papers. It is important to emphasize how all papers used in this study were laboratory papers without any surface finishing treatment, but still their average roughness values are within the range for uncoated papers $\left(R_{a}\right.$ value in range from 3 to $5 \mu \mathrm{m}$ ) [9]. 
Table 4. Topographical parameters of laboratory-made papers

\begin{tabular}{|c|c|c|}
\hline Paper sample & $\mathrm{R}_{\mathrm{a}}(\mu \mathrm{m})[10]$ & $\mathrm{R}_{\mathrm{z}}(\mu \mathrm{m})$ \\
\hline $\mathrm{N}$ & $4.15 \pm 0.34$ & $23.65 \pm 3.28$ \\
\hline $1 \mathrm{NW}$ & $4.13 \pm 0.43$ & $23.15 \pm 2.63$ \\
\hline $2 \mathrm{NW}$ & $4.24 \pm 0.34$ & $23.63 \pm 2.56$ \\
\hline $3 \mathrm{NW}$ & $4.59 \pm 0.51$ & $31.96 \pm 3.80$ \\
\hline $1 \mathrm{NB}$ & $4.06 \pm 0.36$ & $23.60 \pm 3.05$ \\
\hline $2 \mathrm{NB}$ & $4.21 \pm 0.35$ & $23.14 \pm 3.36$ \\
\hline 3NB & $4.24 \pm 0.41$ & $24.39 \pm 2.49$ \\
\hline $1 \mathrm{NTR}$ & $4.25 \pm 0.56$ & $23.68 \pm 2.50$ \\
\hline 2NTR & $4.37 \pm 0.34$ & $24.99 \pm 1.29$ \\
\hline 3NTR & $4.40 \pm 0.39$ & $23.73 \pm 3.28$ \\
\hline
\end{tabular}

Inhomogeneity of the laboratory-made papers as a printing substrate due to its topographical parameter values $\left(R_{a}\right.$ and $\left.R_{z}\right)$ is clearly visible through high standard deviations (SD) of average roughness and maximum peak height values. However, all laboratory-made papers used in this study have quite similar texture.

The contact angles measured for four different liquids are summarized in Table 5. Water, having a predominant polar component over the dispersive component, glycerol and formamide with slightly higher dispersive component than the polar component and diiodomethane, which has no polar component because of its molecular symmetry, were used (Table 3). From the results presented in Table 5 , it can be seen how all analysed laboratory papers show hydrophilic surface $(\theta$ water $<$ $90^{\circ}$ ). Namely, the network of cellulose fibres that have a high affinity to water is the base material in paper [11]. Unsized laboratory papers in contact with water rapidly absorb water as evidenced by a contact angle of less than $90^{\circ}$. It is also evident that the addition of straw pulp into recycled wood pulp for making laboratory papers changes water contact angle by up to $9.5 \%$ in comparison with papers made only from recycled wood pulp. In general, papers containing straw pulp show slightly higher hydrophobicity than those made only with recycled wood pulp $(\mathrm{N})$ which can be explained with the addition of lignin component within the straw pulp [12]. Presence of lignin in a paper sheet increases the hydrophobic character of the paper [11].
Table 5. Contact angles measurements on laboratory-made papers

\begin{tabular}{|c|c|c|c|c|}
\hline \multirow{2}{*}{$\begin{array}{c}\text { Paper } \\
\text { sample }\end{array}$} & \multicolumn{4}{|c|}{ Contact angle $\left({ }^{\circ}\right)$} \\
\cline { 2 - 5 } & Water & Glycerol & Formamide & Diiodomethane \\
\hline $\mathrm{N}$ & $60.22 \pm 1.34$ & $78.41 \pm 1.90$ & $48.96 \pm 3.59$ & $38.91 \pm 2.68$ \\
\hline $1 \mathrm{NW}$ & $57.79 \pm 1.89$ & $78.94 \pm 1.84$ & $44.58 \pm 3.36$ & $39.19 \pm 2.60$ \\
\hline $2 \mathrm{NW}$ & $63.32 \pm 3.34$ & $79.39 \pm 1.64$ & $51.18 \pm 2.29$ & $37.09 \pm 1.51$ \\
\hline $3 \mathrm{NW}$ & $61.46 \pm 2.39$ & $80.08 \pm 2.14$ & $49.67 \pm 1.38$ & $36.11 \pm 1.52$ \\
\hline $1 \mathrm{NB}$ & $61.46 \pm 1.65$ & $80.28 \pm 3.19$ & $47.24 \pm 3.09$ & $38.75 \pm 2.08$ \\
\hline $2 \mathrm{NB}$ & $56.84 \pm 2.11$ & $78.69 \pm 1.59$ & $44.00 \pm 3.02$ & $36.91 \pm 2.08$ \\
\hline 3NB & $60.08 \pm 2.48$ & $78.39 \pm 2.36$ & $46.73 \pm 2.69$ & $38.72 \pm 2.26$ \\
\hline 1NTR & $61.22 \pm 1.76$ & $78.77 \pm 2.71$ & $36.93 \pm 3.37$ & $39.79 \pm 1.83$ \\
\hline 2NTR & $65.98 \pm 2.21$ & $78.04 \pm 2.19$ & $39.92 \pm 4.34$ & $38.29 \pm 2.12$ \\
\hline 3NTR & $61.85 \pm 1.87$ & $73.93 \pm 2.24$ & $38.95 \pm 3.09$ & $38.40 \pm 1.65$ \\
\hline
\end{tabular}

If we look at the contact angles measured on the laboratory papers, we can see that they are quite similar, regardless of the different composition of the paper listed in Table 2 . From this we can conclude that the calculated free surface energy of all analysed papers will be similar, as well as the proportion of polar and disperse components. Table 6 summarizes the results obtained for all paper samples without $(\mathrm{N})$ and with straw pulp, in terms of the total surface free energy $(\gamma)$, dispersive $\left(\gamma^{\mathrm{d}}\right)$ and polar $\left(\gamma^{\mathrm{p}}\right)$ components and dispersive index $\left(\mathrm{X}^{\mathrm{d}}\right)$ calculated by the ratio of the dispersive component to the total surface free energy. All listed values are the average value of at least 10 parallel measurements.

Table 6. Surface free energy and the corresponding dispersive and polar components for the laboratory-made papers determined by contact angle measurements

\begin{tabular}{|c|c|c|c|c|}
\hline \multirow[b]{2}{*}{$\begin{array}{c}\text { Paper } \\
\text { sample }\end{array}$} & \multicolumn{3}{|c|}{ Surface free energy $\left(\mathrm{mJ} \mathrm{m}^{-2}\right)$} & \multirow[b]{2}{*}{$\begin{array}{l}\mathrm{X}^{\mathrm{d}} \\
(\%)\end{array}$} \\
\hline & $\begin{array}{c}\text { Total } \\
\gamma\end{array}$ & $\begin{array}{c}\text { Dispersive } \\
\text { components } \\
\gamma^{\mathrm{d}}\end{array}$ & $\begin{array}{c}\text { Polar } \\
\text { components } \\
\gamma^{\mathrm{p}}\end{array}$ & \\
\hline $\mathrm{N}$ & 40.92 & 30.69 & 10.23 & 75.00 \\
\hline $1 \mathrm{NW}$ & 41.90 & 30.66 & 11.24 & 73.17 \\
\hline $2 \mathrm{NW}$ & 40.18 & 31.63 & 8.55 & 78.72 \\
\hline $3 \mathrm{NW}$ & 40.70 & 31.57 & 9.13 & 77.57 \\
\hline $1 \mathrm{NB}$ & 40.64 & 31.19 & 9.45 & 76.75 \\
\hline $2 \mathrm{NB}$ & 42.59 & 31.28 & 11.31 & 73.44 \\
\hline $3 \mathrm{NB}$ & 41.38 & 31.18 & 10.20 & 75.35 \\
\hline 1NTR & 42.54 & 32.98 & 9.56 & 77.53 \\
\hline 2NTR & 42.06 & 34.67 & 7.39 & 82.43 \\
\hline 3NTR & 43.55 & 34.10 & 9.45 & 78.30 \\
\hline
\end{tabular}

As can be seen from Table 6, paper samples assessed show total surface free energy $(\gamma)$ 
between 40.18 and $43.55 \mathrm{~mJ} \mathrm{~m}^{-2}$. These results obtained for laboratory papers containing straw pulp are within the range intended for uncoated papers $\left(30-50 \mathrm{~mJ} \mathrm{~m}^{-2}\right)$ reported by Örtegren. While, by the same researcher the approximate surface energy values of coated inkjet paper are higher, in the range from 40 to $60 \mathrm{~mJ} \mathrm{~m}^{-2}$ [13]. As well, from Table 6, it is possible to observe that for all paper samples (without and with straw pulp) the predominant component of surface energy is the dispersive component $\left(\gamma^{\mathrm{d}}\right)$ which has a similar value for all papers (ranging from $30.66 \mathrm{~mJ} \mathrm{~m}^{-2}$ to 34.67 $\left.\mathrm{mJ} \mathrm{m}^{-2}\right)$.

For a more visual display of the surface, results obtained for free energy, total surface free energy and the dispersive/polar components of 10 papers in total are presented in Figure 2.

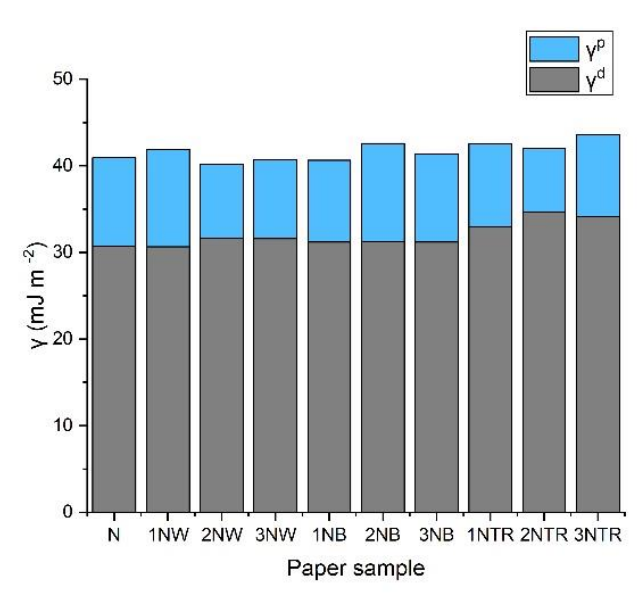

Figure 2. Contribution of the dispersive and polar components to the total surface free energy of laboratory-made paper samples

\section{CONCLUSION}

In this research evaluation of the surface free energy was conducted on laboratory-made papers containing semi-chemical straw pulp (wheat, barley and triticale) in different share. It is important to emphasize that these papers formed at a laboratory scale have not undergone any surface treatment that is characteristic of commercial paper production. However, the results obtained on such papers show how attention should definitely be given to straw as a lignocellulosic material for paper production. Value of topographical parameter $R_{a}$ is slightly increased by the addition of any straw pulp type and consequently rises with the increase in the proportion of straw pulp in the paper. However, these uncoated and unsized surfaces of all laboratory-made papers are within the range for uncoated commercial papers. Regardless of paper composition (portion and type of straw pulp) all analysed laboratory papers show hydrophilic surface $(\theta$ water $\left.<90^{\circ}\right)$. Calculated total surface free energy $(\gamma)$ varies between 40.18 and $43.55 \mathrm{~mJ}$ $\mathrm{m}^{-2}$, which is within the range for uncoated commercial papers. For all paper samples (without and with straw pulp) the predominant component of surface energy is a dispersive component $\left(\gamma^{\mathrm{d}}\right)$.

\section{REFERENCES}

[1] I. Plazonić, Ž. Barbarić-Mikočević, A. Antonović, Chemical Composition of Straw as an Alternative Material to Wood Raw Material in Fibre Isolation, Drvna industrija: znanstveno-stručni časopis za pitanja drvne tehnologije 67(2016) 2, 119-125.

[2] C. Aydemir, A. Karademir, S. İmamoğlu, B.N. Altay, P.D. Fleming, D. Tutak, Investigation of the evolution of hydrophobicity and wettability of paper in multi-color printing process, Cellulose chemistry and technology 53(2019) 7-8, 787-794.

[3] J. Gigac, M. Kasajová, M. Stankovská, The influence of paper surface energy on multicolor offset print mottling, TAPPI Journal 13(2014) 2, 55-64.

[4] I. Moutinho, M. Figueiredo, P. Ferreira, Evaluating the surface energy of laboratory-made paper sheets by contact angle measurements, TAPPI Journal 6(2007) 6, 26-32.

[5] J.M. Schuster, C.E. Schvezov, M.R. Rosenberger, Analysis of the Results of Surface Free Energy Measurement of Ti6Al4V by Different Methods, Procedia Materials Science 8(2015), 732-741. 
[6] N.R. Gómez, E. Quintana, J.C. Villar, Effect of Paper Surface Properties on Coated Paper Wettability with Different Fountain Solutions, Bioresources 9(2014) 3, 4226-4241.

[7] I. Plazonić, Ž. Barbarić-Mikočević, V. Džimbeg-Malčić, Chemical composition of triticale straw as a paper fiber source, Proceedings of joint conference Wood Pulp \& Paper Polygrafia academica, ed. V. Dvonka et. al., Slovenska tehnicka fakulteta v Bratislave, Bratislava, Slovakia, March 12 - 13, 2014, 292-297.

[8] Y. Yuan, R. Lee, Surface Science Techniques, Chapter 1: Contact Angle and Wetting Properties, Springer-Verlag, Berlin, Heidelberg, 2013.

[9] M.A. Hubbe, D.J. Gardner, W. Shen, Contact angles and wettability of cellulosic surfaces: A review of proposed mechanisms and test strategies, Bioresources 10(2015) 4, 8657-8749.

[10] I. Plazonic, I. Bates, Z. BarbaricMikocevic, The Effect of Straw Fibers in Printing Papers on Dot Reproduction Attributes, as Realized by UV Inkjet Technology, BioResources 11(2016) 2, 5033-5049.

[11] A. Liukkonen, Contact Angle of Water on Paper Components: Sessile Drops versus Environmental Scanning Electron Microscope Measurements, Scanning 19(1997), 411-415.

[12] I. Plazonić, Ž. Barbarić-Mikočević, V. Džimbeg-Malčić, Chemical composition of wheat straw as a potential raw material in papermaking industry, Proceedings Natural resources, green technology \& sustainable development, ed. I. Radojčić Redovniković, T. Jakovljević, J. Halambek, M. Vuković, D. Erdec Hendrih, Faculty of Food Technology and Biotechnology, University of Zagreb, Zagreb, Croatia, November 26 - 28, 2014, 131-135.

[13] J. Örtegren, Paper surfaces in digital printing, FPIRC Course \#14: PAPER SURFACES - Characterization and properties, KTH Solid Mechanics, Stockholm, September 15-18, 2014.
https://www.fpirc.kth.se/Documents/PD F/paper\%20for\%20Inkjet2.pdf, Accessed: May 21, 2019.

\section{Acknowledgements}

This work has been supported in part by Croatian Science Foundation under the project "Printability, quality and utilization of substrates with non-wood fibers" (UIP-201705-2573). 